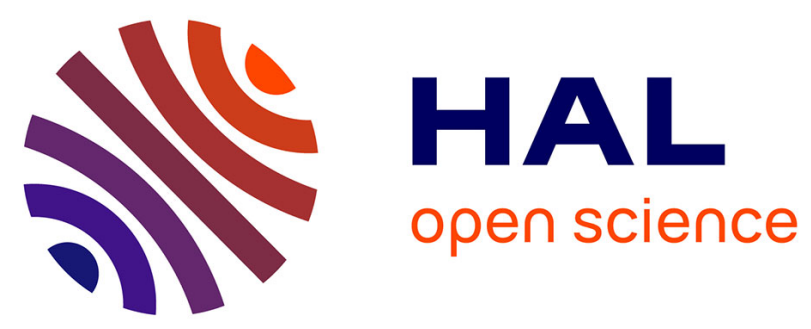

\title{
Modular precast concrete facing for soil nailed retaining walls: Laboratory study and in situ validation
}

Tan Trung Bui, Marion Bost, Ali Limam, Jean-Pierre Rajot, Philippe Robit

\section{To cite this version:}

Tan Trung Bui, Marion Bost, Ali Limam, Jean-Pierre Rajot, Philippe Robit. Modular precast concrete facing for soil nailed retaining walls: Laboratory study and in situ validation. Innovative Infrastructure Solutions, 2019, 24 p. 10.1007/s41062-019-0250-z . hal-02415778

\section{HAL Id: hal-02415778 \\ https://hal.science/hal-02415778}

Submitted on 17 Dec 2019

HAL is a multi-disciplinary open access archive for the deposit and dissemination of scientific research documents, whether they are published or not. The documents may come from teaching and research institutions in France or abroad, or from public or private research centers.
L'archive ouverte pluridisciplinaire HAL, est destinée au dépôt et à la diffusion de documents scientifiques de niveau recherche, publiés ou non, émanant des établissements d'enseignement et de recherche français ou étrangers, des laboratoires publics ou privés. 


\title{
Modular precast concrete facing for soil nailed retaining walls: Laboratory study and in situ validation
}

\author{
T. T. Bui' ${ }^{1}$ M. Bost ${ }^{2}$, A Limam², J.P. Rajot ${ }^{2}$, P. Robit ${ }^{3}$ \\ ${ }^{1}$ University of Lyon, INSA Lyon, GEOMAS, France \\ ${ }^{2}$ IFSTTAR, GERS-RRO, Bron, France \\ ${ }^{3}$ NGE FONDATION, Saint-Priest, France
}

\begin{abstract}
A new concept for constructing the facing of soil nailed walls is proposed and validated through experimental and numerical approaches. This new process uses precast concrete panels. For each excavation step, the soil reinforcements are first connected to the panels. A slightly cemented 4-6 mm crushed stone is then injected, through the weep holes, between the panels and the excavation vertical cut, applying a confining pressure to the ground and providing continuous high capacity drainage behind the facing. The structural design of the precast reinforced concrete panel, based on full scale loading tests in the laboratory and nonlinear numerical simulations, are presented in detail. Crack initiation and failure modes are properly predicted by the model. A full-scale experimental soil nailed wall $7.5 \mathrm{~m}$ high was also built to evaluate the environmental, economic and mechanical performances of the new construction technique compared to the conventional shotcrete technique. The new construction technique greatly improves worker's safety, significantly reduces construction duration and cost and improves the mechanical behavior of the soil nailing technique and drainage of the facing. Compared to the conventional shotcrete technique, the new technique reduces concrete consumption by $64 \%$ and greenhouse gases emission by $56 \%$.
\end{abstract}

Keywords: retaining wall; soil nailing; precast concrete; experiment; numerical simulation.

\section{Introduction}

Soil nailing is frequently used to stabilize natural slopes, temporary excavations, long term road widening, tunnel heads, underground parking facilities, etc. It may be viewed as a soil retention technique using grouted tension-resisting steel elements, attached to a facing, to support an excavation or stabilize steep cuts under static and seismic conditions [1]. In fact, the interaction between the soil and structural reinforcing elements installed in the ground is a complex topic in soil mechanic. This interaction involves combined axial and transverse efforts in the linear structural elements, whose values depend on local mobilization of soil strength and on global deformation behaviour of the entire reinforced soil mass. Case histories and postearthquake surveys show that soil nailed walls have performed extremely well during strong ground motions compared to most gravity retaining structures [2] [3]. 
Subsequent information for the design and construction of soil nailed walls may be found in [4] and [5], by Juran (1987) and Bruce et al. (1986) respectively. These recommendations were based on the study of measurements made on many full-scale trials and model tests during construction of real projects. In France, the design method recommended by CLOUTERRE for soil nailed walls relies on an ultimate limit state analysis with partial safety factors considering four potential failure modes [6]. Both of these design methods have been checked against experimental results in full scale structures at failure from the CLOUTERRE National Project.

After each excavation step and installation of sub-horizontal reinforcements in the natural soil, a drainage complex and a structural facing must be placed to mobilize a confining pressure in the ground before the next excavation step and transition to the long-term behaviour of the soil occurs. The conventional and widely used technique for constructing this facing consists of several passes of shotcrete on two reinforcing steel meshes. Examples of facing construction using shotcrete in recent projects are shown in [1] and [7]. During this construction process a significant amount of concrete is lost, bouncing off the vertical reinforcing steel meshes during projection. This method of construction is thus expensive and represents a waste for the natural resources and the environment.

An alternative process to shotcrete facing construction for soil nailed walls was therefore proposed. This process is based on using precast concrete panels, which are easier to install, cheaper and made of concrete with controlled mechanical properties. Various aesthetic surface texture may be added to the panels, whereas shotcrete is uniform, grey and rough. To gauge all aspects of this new concept, a real scale soil nailed wall had to be built and instrumented. In fact, for the purpose of objective comparison the conventional technique (shotcrete), two full scale instrumented walls were constructed adjacent to each other, both $7.50 \mathrm{~m}$ high, $10 \mathrm{~m}$ long, with identical soil reinforcements. As shown in an elevation view in Figure 1, however, the facing of first one (on the left in the figure) was constructed with the conventional shotcrete technique while the second was built with precast concrete panels. 


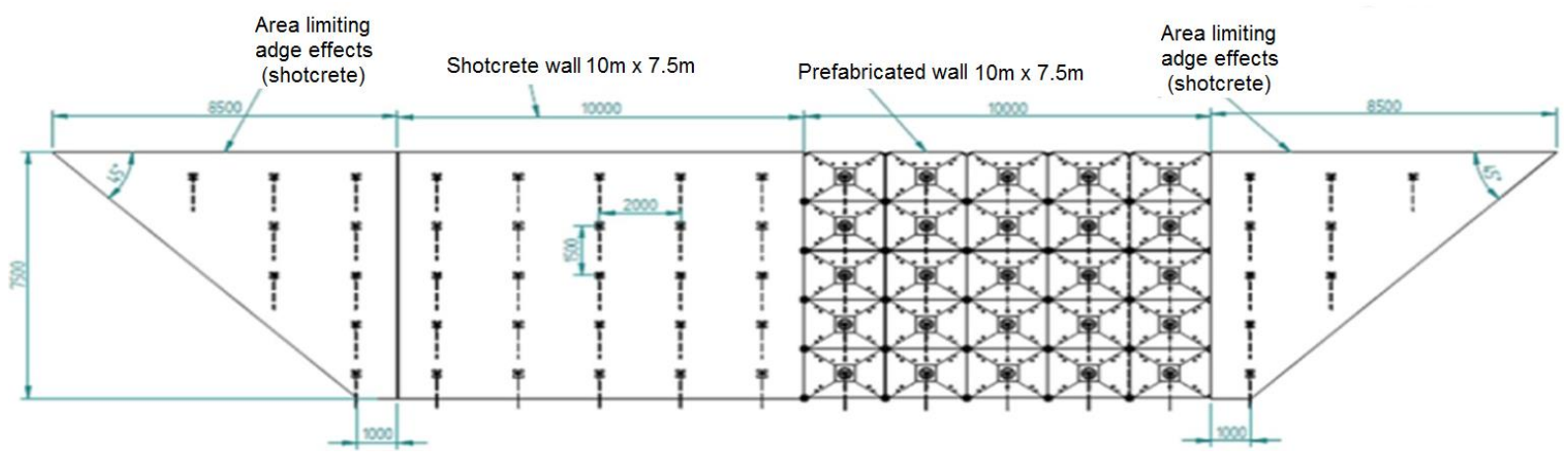

Figure 1. Full-scale soil nailed walls (Bevenais, France): shotcrete facing - left side, precast panels - right side (quoted distances in $[\mathrm{mm}]$ ).

The first part of this study concerns the load capacity and the associated failure mode of a single precast reinforced concrete panel, in order to assess its structural design. An experimental study was performed in the laboratory [8], subjecting a panel to unfavourable mechanical loading conditions compared to the field, where the reinforcement applies a load at the centre and the soil a distributed pressure on the opposite surface. A numerical model was developed to extend experimental test conclusions. Experiments and simulations allowed evaluating the load applied by the reinforcement corresponding to crack initiation, cracking behaviour (opening and propagation) and, finally, the ultimate state or load capacity as well as the associated failure mode. The reinforced concrete panel geometry and steel reinforcement were designed to sustain the soil reinforcement axial strength.

The second part of this study concerns the evaluation of the new construction process and the compared behaviors of the two full-scale soil nailed walls. Precast panels designed based on the experimental tests and numerical study in first part of this study, were used in the field.

\section{Concrete precast panel of the modular soil nailed retaining wall: Laboratory tests}

\subsection{Precast elements and their connections}

In view of the industrialization of the process, the different projects conducted these last years for different configuration sites and soil nailing designs were analysed. A standardization of the precast panel surface to $3 \mathrm{~m}^{2}$ appeared to be an optimal choice. In the geotechnical design of the soil nailing for the execution project, the vertical spacing between two horizontal rows of reinforcements was taken equal to $1.5 \mathrm{~m}$ and the horizontal spacing to $2 \mathrm{~m}$. The length of the reinforcements and their tension depend on the geotechnical conditions and wall geometry.

Figure 2 shows the precast elementary panel, called "scale" of the facing. The reservation hole at the center of the scale will coincide with the reinforcement's head. The steel bar of the reinforcement will go through this hole and be tied to the facing with a bearing plate and a nut. 
To reduce concrete material consumption, a linear variation of the thickness of the precast slabs was adopted. Since external load is concentrated at the center of the panel, where the anchorage is connected, a pyramidal shape was adopted. At each corner, a mechanical device is installed during construction to connecting adjacent panels to form the wall's facing. This device was designed to ensure continuity of the three displacements but to allow rotations between panels. The precast panels and the connecting device were designed to withstand the maximum allowable tension force in the reinforcement considering the panel simply supported at its four corners only, which is unfavorable compared to its actual loading conditions in the facing of soil nailed walls, where tension in the reinforcement is balanced by earth pressure and shear forces between panels are limited.

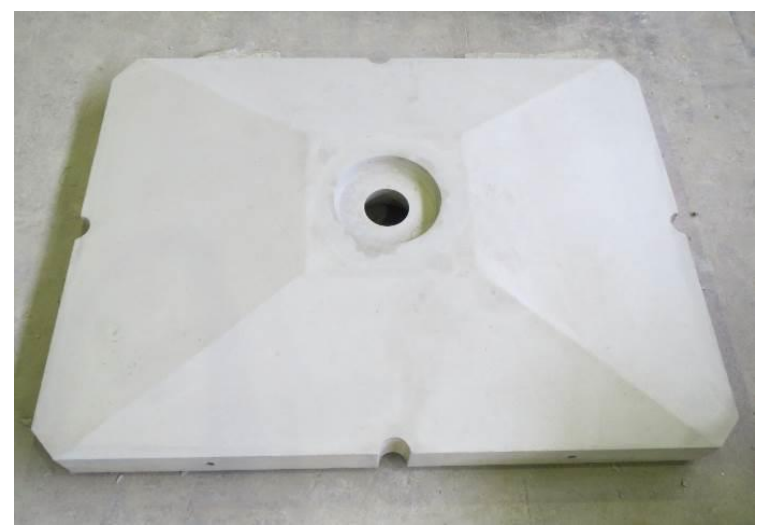

(a) Standard Panel, $2 \mathrm{~m}$ wide by $1 \mathrm{~m}$ high

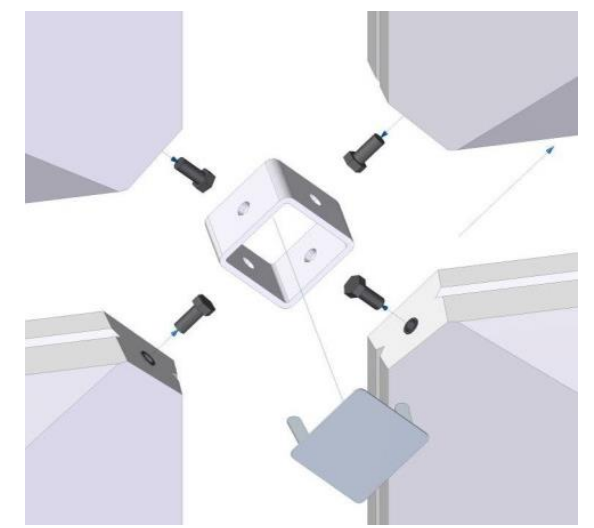

(b) Example of connecting device

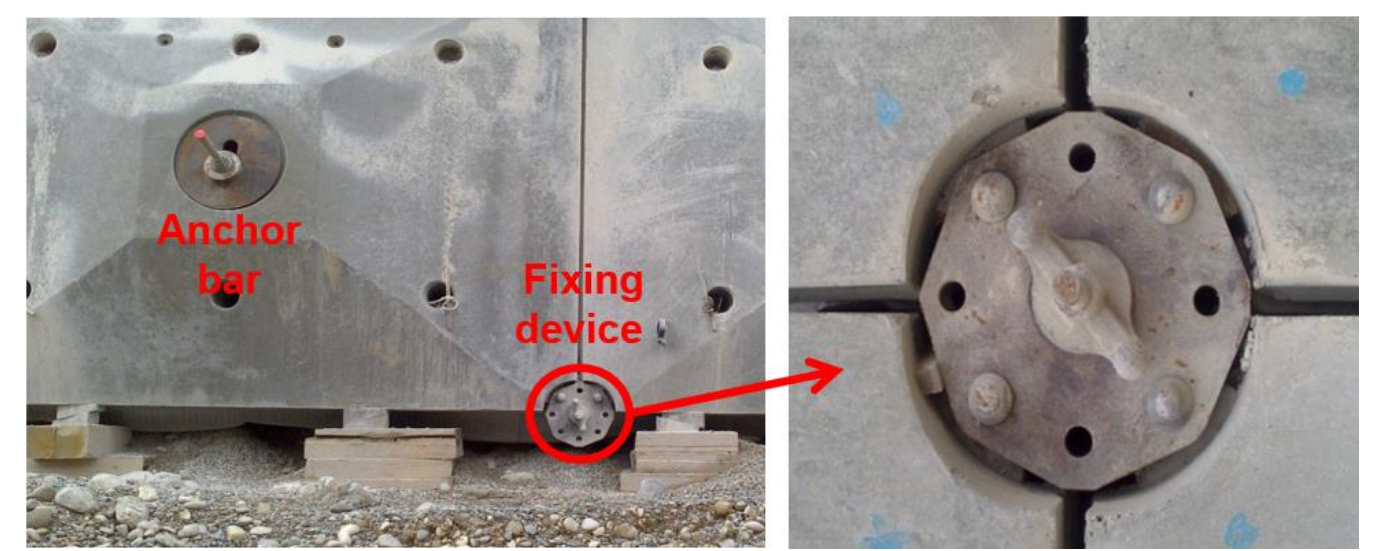

(c) Facing panel with connection device installed in the experimental wall

Figure 2. Precast panel, $2 \mathrm{~m}$ wide and $1.50 \mathrm{~m}$ high, and connecting device at the four corners

\subsection{Specimens characteristics and test setup}

To evaluate the behavior of a precast panel subjected to representative mechanical loading conditions, two tests were carried out on identical specimens $2 \mathrm{~m}$ wide by $1.50 \mathrm{~m}$ high (see Figure 2). The objective was to quantify the onset of cracking as well as to evaluate the bearing capacity and the failure mode of the panel. The specimens were cast using ready-mixed concrete of class C40/50. The compressive strength of the concrete mixture used for the slabs 
was determined from compression tests on $11 \times 22-\mathrm{cm}$ cylindrical specimens performed during the day where the panel was tested. An average unconfined compressive strength value of 56.3 MPa was found.

As shown in Figure 3, the test on the panel specimens consisted in applying a quasi-static load at the center of the upper side of the pyramidal panel specimen, where the soil reinforcement is connected to the facing. The specimen was supported by four cylindrical plates. An incremental quasi-static load was applied (imposed force) at the center by a hydraulic jack with a load speed of $1 \mathrm{kN} / \mathrm{s}(60 \mathrm{kN} /$ minute). The specimen displacements were observed using five LVDT gages.
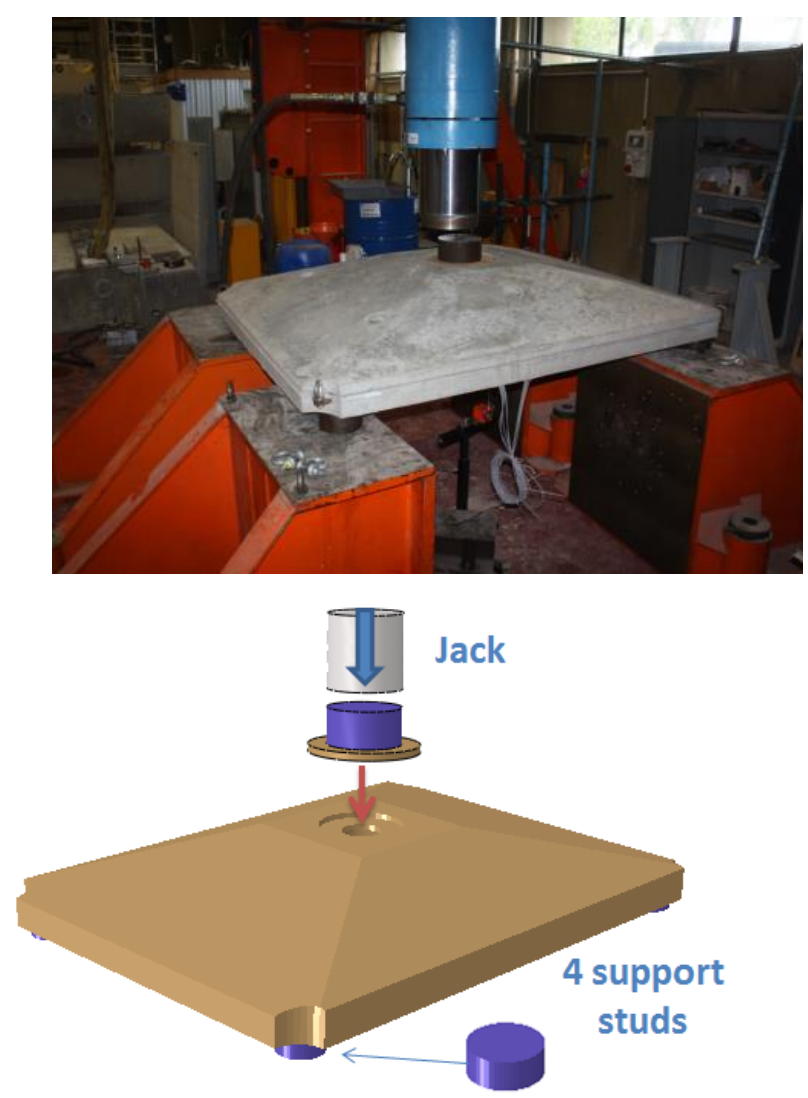

Figure 3. Test setup for the specimen of precast concrete panel

The rebar, amount, spacing, and the diameter of longitudinal and transverse steel reinforcement are given in Figure 4. For the lower reinforcement layout, the longitudinal and transversal reinforcement consisted of $\varnothing 8 \mathrm{~mm}$ with a spacing of $100 \mathrm{~mm}$. For the upper reinforcement layout, the longitudinal and transversal reinforcement consisted of $\varnothing 6 \mathrm{~mm}$ with spacing of $200 \mathrm{~mm}$. Two rebar circles placed at the centre of the slab with the diameters of $\varnothing 10 \mathrm{~mm}$ were added to reinforce the concrete about the concentrated load location. The cross longitudinal bars connecting two opposite corners of the panel were $\varnothing 10 \mathrm{~mm}$ in diameter 
(Figure 4b). The yield strength of the steel reinforcement was $f_{y}=500 \mathrm{MPa}$ and the ultimate strength was $f_{u}=540 \mathrm{MPa}$. The concrete cover was $30 \mathrm{~mm}$.

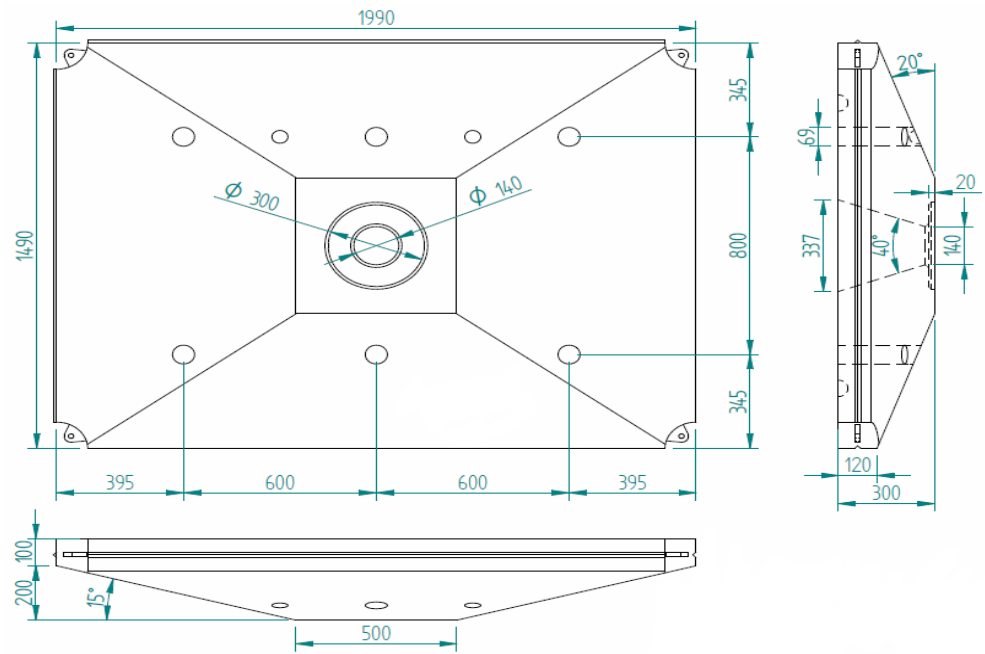

a)
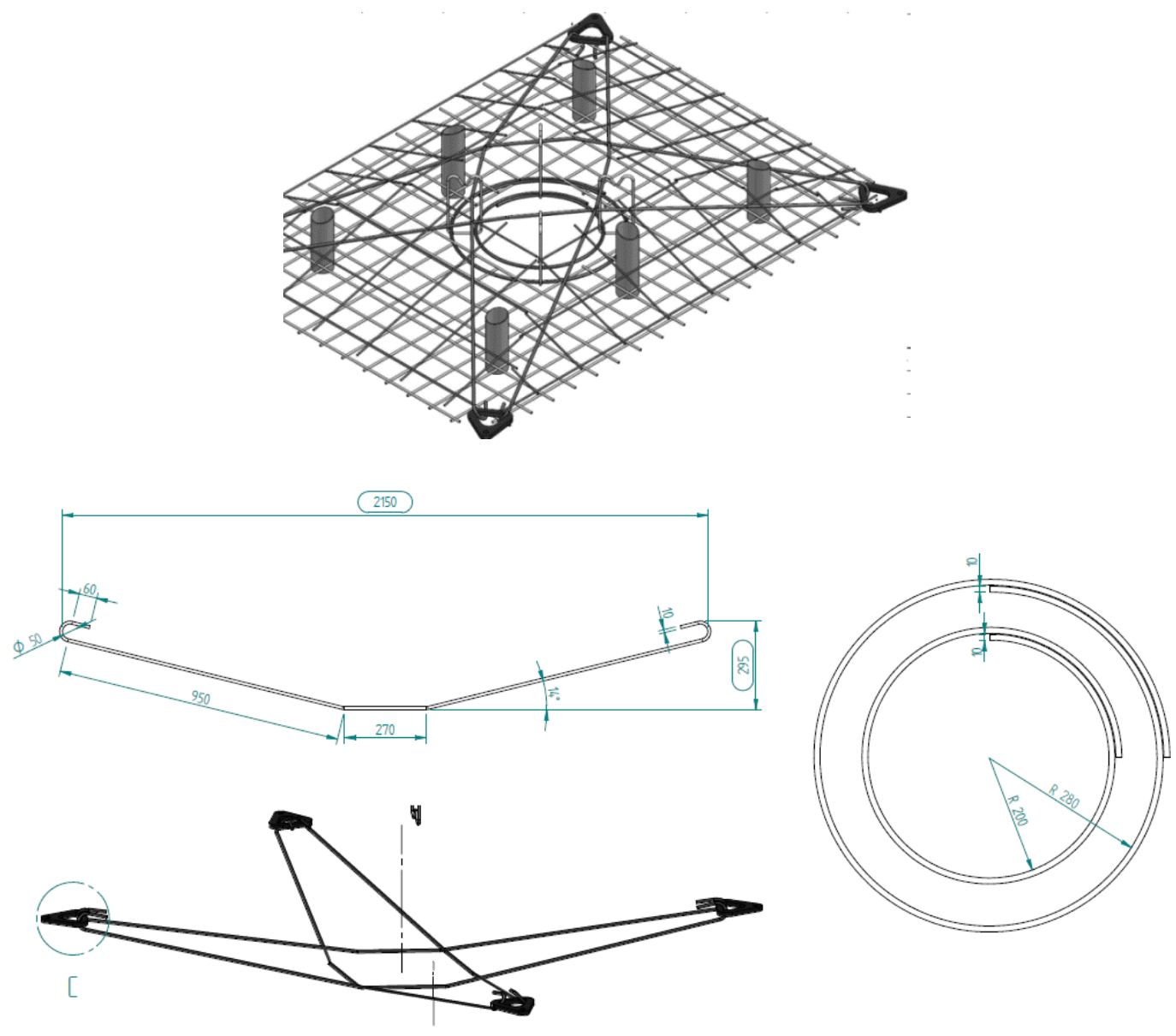

b) 
Figure 4. Dimension of the precast concrete slab and steel rebar reinforcement: a) Scale geometry (quoted distance in $\mathrm{mm}$ ) ; b) Steel reinforcement arrangement

\subsection{Experimental results}

Two loading tests were performed in the laboratory. The load/deflection curves of the two tests are shown in Figure 5. The limit of linearity obtained on the load/deflection curves is about $140 \mathrm{kN}$. The ultimate load is $407 \mathrm{kN}$ for Specimen 1, and $413 \mathrm{kN}$ for Specimen 2. Both tests give very similar results. An excellent test reproducibility may be noted in all the loading phases characterising the behaviour, from the elastic part at the beginning of loading to the ultimate state. The difference of ultimate load between the two tests is lower than $1.5 \%$.

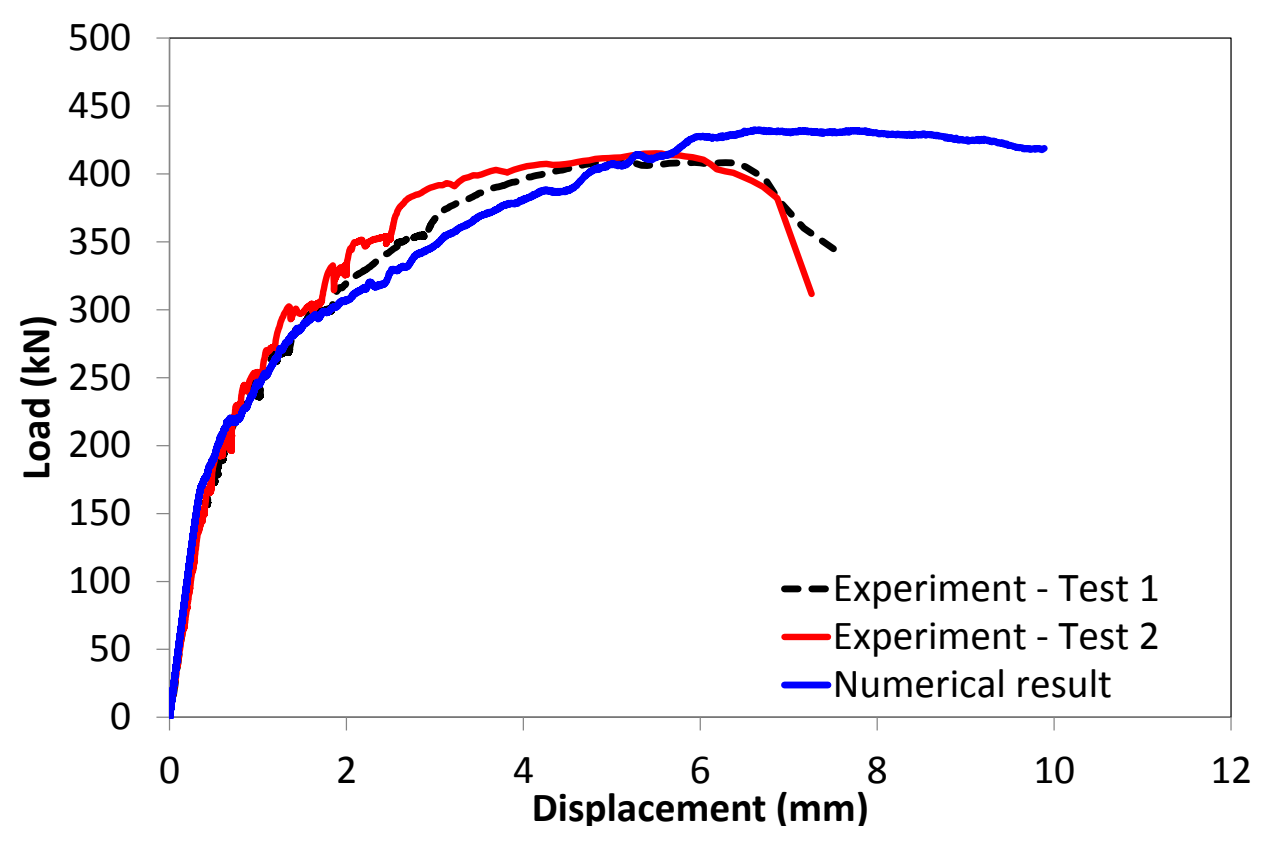

Figure 5. Load/displacement curves: experimental vs numerical results

The failure modes observed for Specimen 1 may be defined by the pattern of cracks shown in Figure 6. On the bottom face, the failure due to bending in both directions has been found. The cracks correspond to the flexural rebar's positions. On the top face, shear cracks were also observed at the four corners of the specimen. 

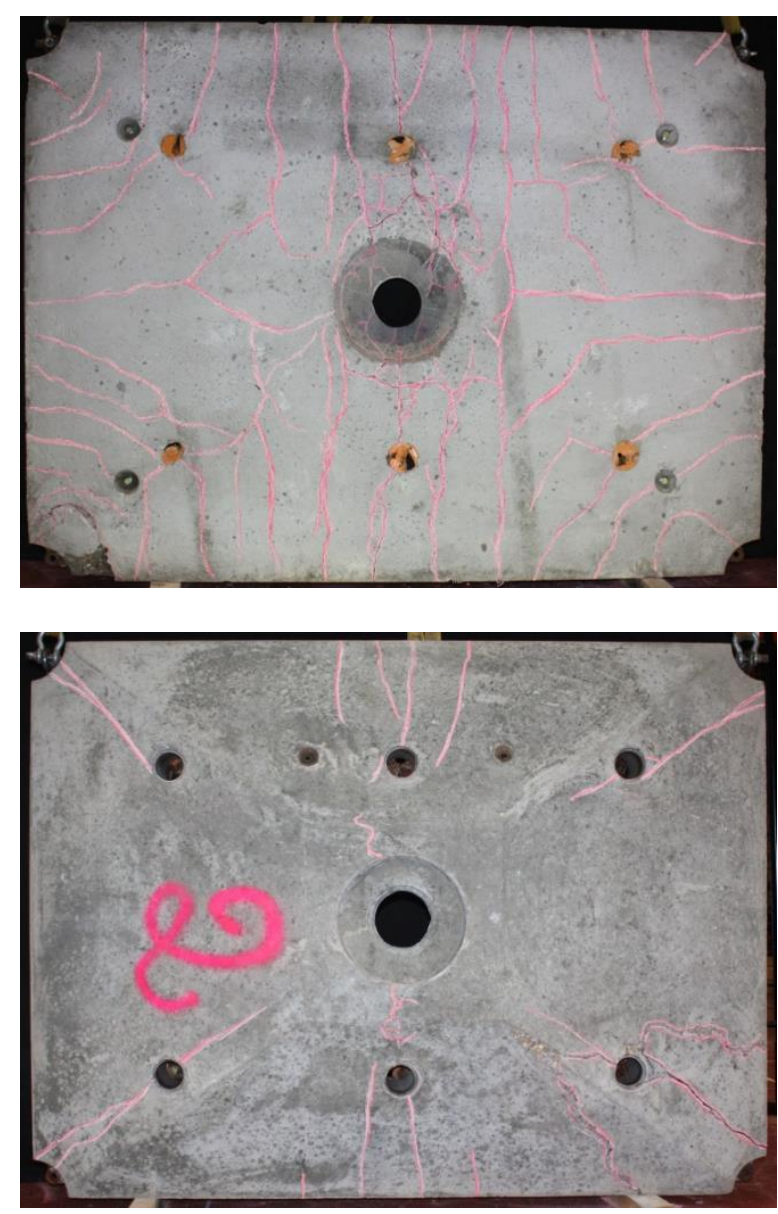

Figure 6. Cracks observed on Specimen 1: bottom face and top face

\subsection{Numerical model and materials law}

The numerical investigations were conducted with Abaqus explicit software. The failure of RC slabs can be sudden, in particular for failure in shear. This could cause numerical instability and convergence problems in case of traditional quasi-static analysis (implicit incremental analysis). Therefore, the explicit method was used with very small load increments considering a so-called smooth-step function to develop quasi-static analysis. All calculations were made force controlled with an explicit solution technique. The computing time corresponding to the critical increment size is considerably shorter than the computing time under application of implicit solvers. But the total computing time associated with the explicit simulation is much lower to the one associated to the implicit simulation, knowing that implicit method suffers many convergence problems due to singularities of tangent stiffness matrix induced by cracks appearance along the equilibrium path. The concrete damaged plasticity model (CDP) in Abaqus was used for concrete material and the classic elastic-plastic model was applied to reinforcement steel. 
The CDP model in Abaqus is based on the models initially proposed by Lubliner et al. (1989) [11] for monotonic loading, and developed later by Lee and Fenves (1998) [12] to consider the dynamic and cyclic loadings. The constitutive theory aims to capture the effects of irreversible damage associated with the failure mechanisms that occur in concrete and other quasi-brittle materials under fairly low confining pressures (less than four or five times the ultimate compressive stress in uniaxial compression loading). The nonlinear behaviour of concrete is attributed to the damage and plasticity processes. The plastic behaviour can be characterized by several phenomena such as strain softening, progressive deterioration, etc. The damage process can be attributed to micro-cracking. Damage is associated with the concrete's failure mechanisms and therefore results in a reduction of the elastic stiffness. The model is based on the concept of isotropic damaged elasticity in combination with isotropic tensile and compressive plasticity to represent the inelastic behaviour of concrete i.e. tensile cracking and compressive crushing. The relevance of CDP model to simulate the reinforced concrete structures has been validated by several authors in recent studies [13][14]. Due to the complexity of the selected geometric shape, a 3D finite element model developed with solid element has been chosen. The modeled geometry is identical to the real geometry and accounts for the presence of the steel reinforcements in the concrete panel. For symmetry reasons, only one quarter of the slab was modeled. Boundary conditions correspond to two plane of symmetry and one support (downwards displacement is zero) at the slab corner. Uniform pressure is applied to the ring in the central part of the top surface (Figure 7), at the location of the loading jack in the experiment.

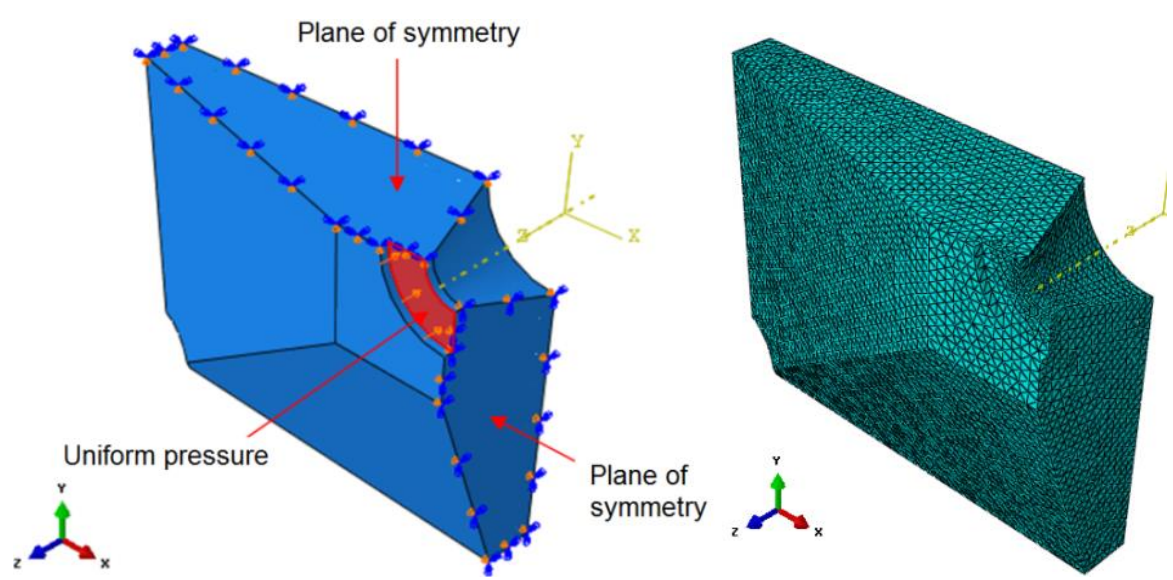




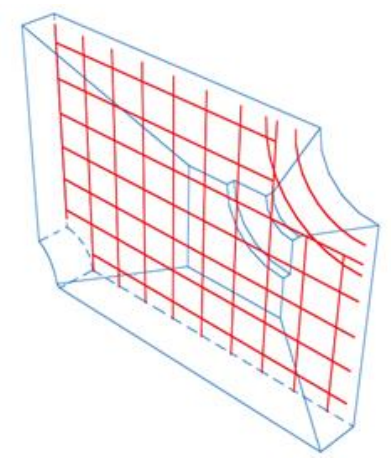

Figure 7. Finite Element mesh of one fourth of the precast panel

The characteristics of C40/50 concrete are given in Table 1. For steel reinforcement type Fe500, an elastoplastic model with isotropic hardening is used. The characteristics of the reinforcements are specified in Table 2.

Table 1. Properties of concrete used in numerical model

\begin{tabular}{lc}
\hline \multicolumn{1}{c}{ Characteristics } & Value \\
\hline Compressive strength $\mathrm{f}_{\mathrm{ck}}$ & 40 \\
$(\mathrm{MPa})$ & 3.5 \\
Tensile strength $\mathrm{f}_{\mathrm{ct}}(\mathrm{MPa})$ & 35000 \\
Young's modulus $(\mathrm{MPa})$ & \\
\hline
\end{tabular}

Table 2. Properties of steel used in numerical model

\begin{tabular}{cc}
\hline Characteristics & Value \\
\hline Young's modulus $(\mathrm{GPa})$ & 210 \\
Yield strength $\mathrm{f}_{\mathrm{yk}}(\mathrm{MPa})$ & 500 \\
Rupture strength $(\mathrm{MPa})$ & 540 \\
\hline
\end{tabular}

A perfect adhesion between steel rebar and concrete is assumed. This modeling is fairly faithful to the test.

\subsection{Numerical results and analysis}

Figure 5 shows that the load/deflection curve obtained numerically at the central point instrumented by sensors (Displacement transducer and load sensor) compares well with those observed during the tests. For the linear phase of the load-deflection curve, the rigidity obtained numerically is similar to that found experimentally, but also the non-linear behavior is correctly reproduced, showing the relevance of the numerical model. The ultimate load obtained by the 
numerical computation is of $452 \mathrm{kN}$. This value is $11 \%$ higher than the maximum load observed in experimental test on Specimen $1\left(\mathrm{P}_{\text {exp-test1 }}=408 \mathrm{kN}\right)$ and $9 \%$ higher than that of experimental test on Specimen $2\left(\mathrm{P}_{\text {exp-test } 2}=415 \mathrm{kN}\right)$. The elastic limit (beginning of cracking) is also quite well reproduced by the simulation $\left(\mathrm{P}_{\text {elas-FEM }}=160 \mathrm{kN}, \mathrm{P}_{\text {elas-exp }}=140 \mathrm{kN}\right)$, with a difference of about $14 \%$. It is also important to emphasize that the bearing capacity of the concrete panel, as a prefabricated structural component of the facing of a soil nailed wall, is properly designed, since the maximum tensile load of the steel bar in the soil reinforcement, a Gewi bar of diameter $25 \mathrm{~mm}$ with yield stress of $670 \mathrm{MPa}$, is $329 \mathrm{kN}$.

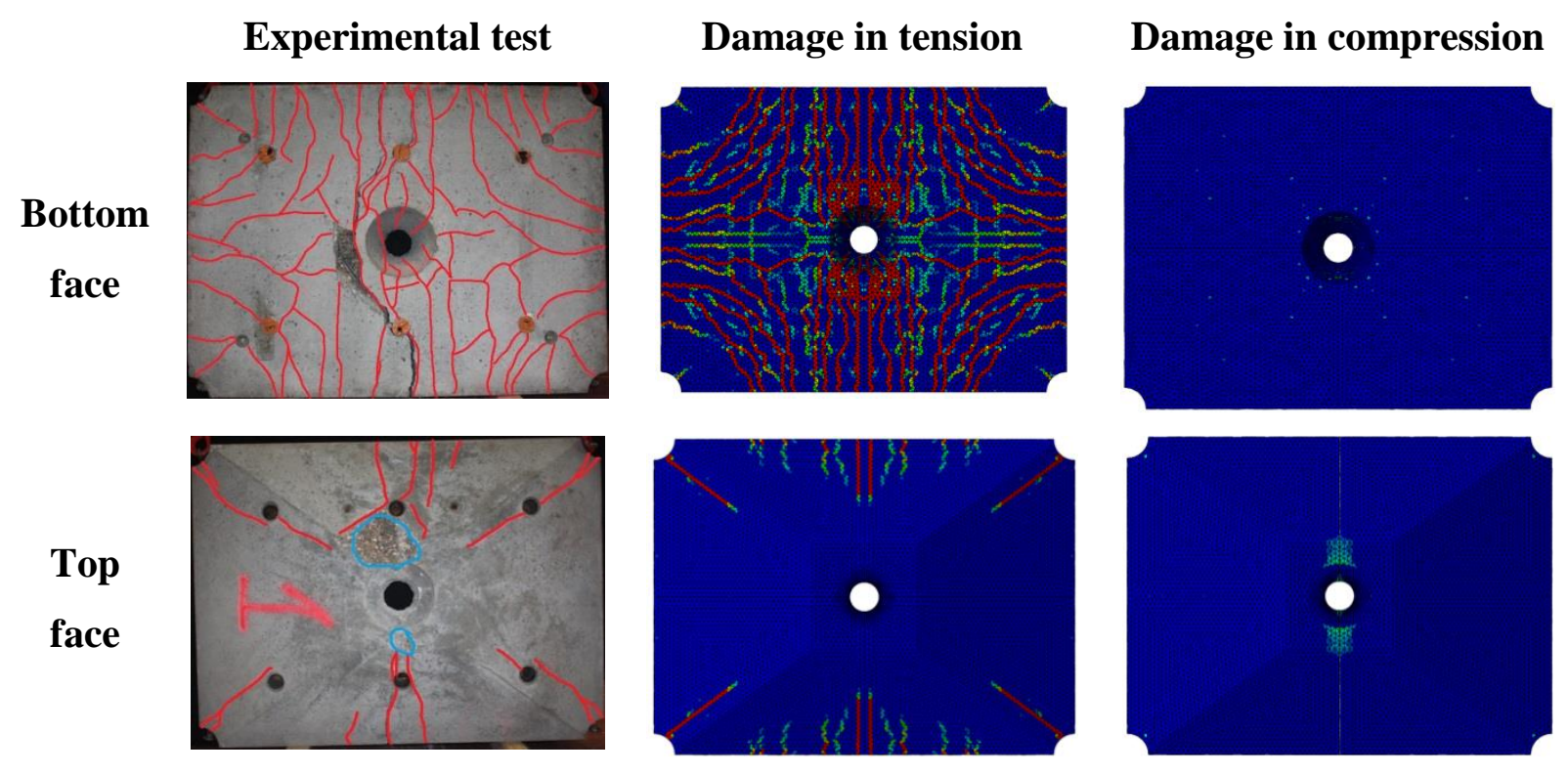

Figure 8. Failure modes: experimental vs numerical results (Specimen 2)

Numerical simulation leads to a final failure mode in bending, with essentially two cracks propagating half way across the panel. This is also confirmed by observing the plastic deformations of longitudinal reinforcement when the ultimate load is reached. The numerical and observed cracking patterns are similar as showed in Figure 8. Using the variables of damage we can visualize where cracking develops in the model. On the lower face (tensile face), most cracks are due to traction. On the upper face, there is an area about the hole at the center of the panel where the failure is obtained by damage in compression of the concrete. This damage was also observed experimentally (crushing of the concrete around the hole). Tensile cracks also appear on the upper face, which propagate from the cracks observed initially on the lower face. These appear at the four corners of the panel and also on the long span (width of panel), whereas no crack appears on the smallest span (height of panel).This indicate a bending failure in only one direction, which confirms a beam-like behavior (one way direction of solicitation). The first cracking observed is the longitudinal crack due to bending. We recall that this test is very conservative compared to the actual loading of the panel in the facing of a soil nailed wall. 


\section{In situ full scale evaluation of the new construction technique}

The second part of this study was focused on the evaluation of the performance of the new technique for constructing the facing of soil nailed walls, based on the precast panels whose structural design was presented in the preceding section. For that purpose, an excavation $20 \mathrm{~m}$ long and $7.5 \mathrm{~m}$ deep with vertical cut was created using soil nailing at a site located in Bevenais, France. The design of the soil reinforcement was performed according to Eurocode 7, French National Application Standard NF P 94270.

The usual construction process for soil nailed excavations was applied, with successive excavation stages, each one corresponding to a single horizontal row of reinforcements, then drilling for installing and grouting the reinforcements steel bars in the soil and, finally, constructing the facing for the current reinforcement row, before the next excavation stage. However, as shown in the photo of the completed excavation in Figure 9, the facing was built using, for half of its length, on the left side, the conventional shotcrete technique and, on the right side, the new technique.

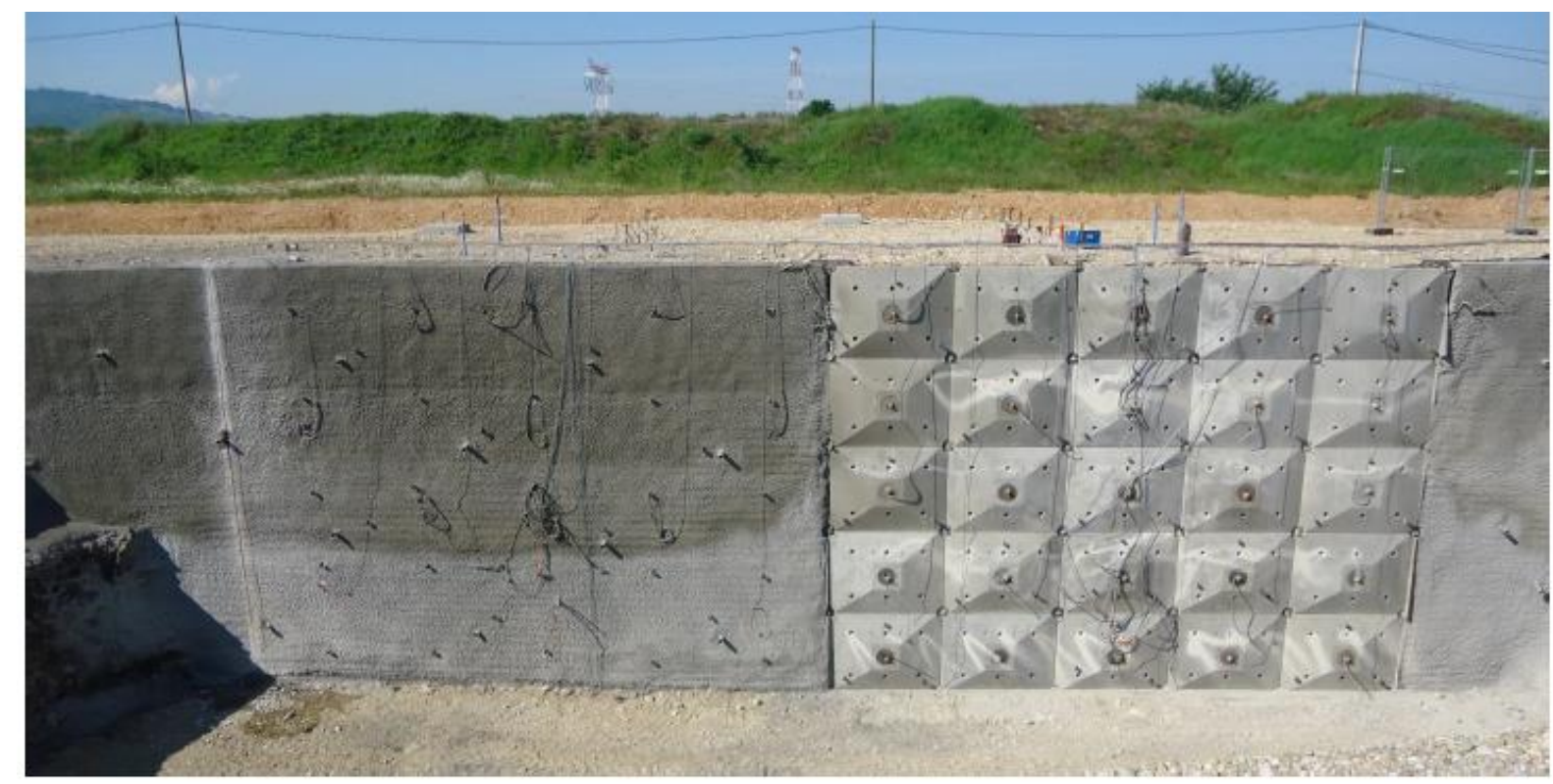

Figure 9. In situ full-scale soil nailed walls built in Bevenais, France

(left side, shotcrete facing - right side, precast panels)

During construction, the economic performance of each of the construction technique was precisely evaluated considering labor time, equipment needed and material supply. Furthermore, this experimental setup allowed direct comparison of the influence of the facing construction technique on the behavior of soil nailed retaining walls. During construction and for two years after the end of construction, the horizontal displacements of the facing and the tension forces distributions along the reinforcements were monitored and have been analyzed. 


\subsection{Construction of the experimental soil nailed wall in the field}

The geotechnical soil profile at the construction site consisted of a clean and well graded gravel layer whose thickness was larger than $30 \mathrm{~m}$. An unconfined aquifer with horizontal water table was observed at a depth of about $30 \mathrm{~m}$, way below the bottom of the excavation project. In situ total unit weight of the soil was evaluated to $22.5 \mathrm{kN} / \mathrm{m}^{3}$ and natural water content to $4 \%$. Based on grain size distribution and dry density, the effective friction angle was estimated to be about $41^{\circ}$ and, for design, effective cohesion was considered to be negligible. A pressuremeter boring showed that, over the excavation depth, the Menard Limit Pressure was about $5 \mathrm{MPa}$ and the Menard Modulus $40 \mathrm{MPa}$.

According to the geotechnical design, the soil reinforcement consisted of five horizontal rows of steel bars, with vertical spacing of $1.5 \mathrm{~m}$ and horizontal spacing of $2 \mathrm{~m}$, installed into boreholes drilled with a $10^{\circ}$ angle dip below the horizontal. From the top, the first two upper rows were $7 \mathrm{~m}$ long, the next two rows $6 \mathrm{~m}$ and the lowest row $5 \mathrm{~m}$. All the bars were $25 \mathrm{~mm}$ diameter GEWI bars made of high yield strength steel (670 MPa).

To install the soil reinforcements into such a soil, ODEX air drilling technique with continuous casing was employed. The theoretical diameter of the borehole (the boring diameter) was $115 \mathrm{~mm}$. The steel bars with centering devices were then placed into the borehole and casing was progressively removed while cement slurry was injected from the lower end of the boring into the ground, up to the reinforcement head at the facing. The cement over water mass ratio of the slurry was equal to 2 to avoid cement settling.

Several reinforcement pullout tests were performed to evaluate the strength of the soil cement grout interface. In those tests, the drilling, bar placement and grouting equipment and procedures were the same as those in the actual soil nailed wall, except for the orientation (pull out tests were vertical) and the length. In the tests, boring length was $3 \mathrm{~m}$ and only the lower $2 \mathrm{~m}$ of the bars were grouted to create the sealing bulb. The volume of cement slurry injected per meter of reinforcement corresponded to about twice the theoretical boring diameter, indicating irregular borehole walls and penetration of cement slurry into the granular soil. During the tests, the maximum tension force applied at the reinforcement head turned out to be limited by the tensile strength of the steel bar, not the resistance of the anchored zone. Thus, for the design, the strength of the soil - cement grout interface was assumed to be larger than $638 \mathrm{kPa}$, considering for design the theoretical borehole diameter of $115 \mathrm{~mm}$, or larger than $452 \mathrm{kPa}$, considering for design a borehole diameter of $162 \mathrm{~mm}$ corresponding to the volume of slurry injected per meter. 
The usual construction process for soil nailed walls was applied. For each of the successive excavation stages, a horizontal row of reinforcements was installed in the ground as described previously and a horizontal strip of facing was constructed, using shotcrete on the left side of the wall and precast panels on the right, before proceeding to the next excavation stage.

Figure 10 is a picture showing two workers applying the first shotcrete layer to create the facing. Vertical trips of a draining complex have first to be placed against the vertical cut in the ground. The first reinforcing steel mesh is then attached to be maintained at the right location in the project during application of the first shotcrete layer, requiring several projections passes. After about one day, the second steel mesh is also attached with spacers to ensure the specified distance to the first mesh and the second layer of shotcrete is applied.

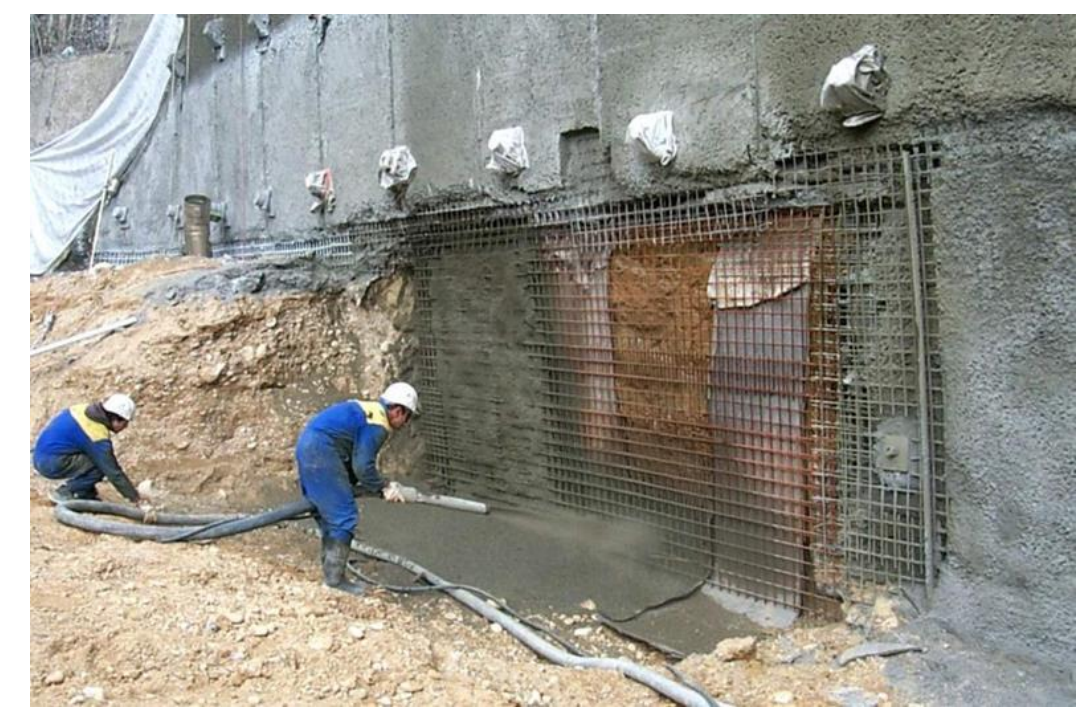

Figure 10. Construction of the facing for one excavation stage using shotcrete

In addition to safety concerns for the workers applying shotcrete (eye injuries, sudden clogging of the projection pipe), this in situ construction of the facing using shotcrete presents several drawbacks. A gap may exist between the draining complex and the ground behind it, which may be filled by eroded fine soil particles. Finally, a very large amount of concrete is wasted for two reasons. First, to fill up the volume between the specified location of the facing in the project and the soil surface after vertical excavation, i.e. the so called "out of profile volume." This volume may be very large in granular soils, which require short term vertical support and are prone to soil disturbance during drillings to install the reinforcements.

Second, as illustrated in Figure 11, due to rebound of a significant amount of concrete on steel meshes and to poor adhesion to the draining complex or to the ground, since projection is impeded by the steel mesh. The picture on the right side in the figure shows that the thickness of wasted concrete due to rebound was of the order of $20 \mathrm{~cm}$, close to the $25 \mathrm{~cm}$ specified wall 
thickness. As mentioned earlier, its actual thickness was even larger due to "out of profile" during the excavation stage and to disturbance of the soil during reinforcement installation.
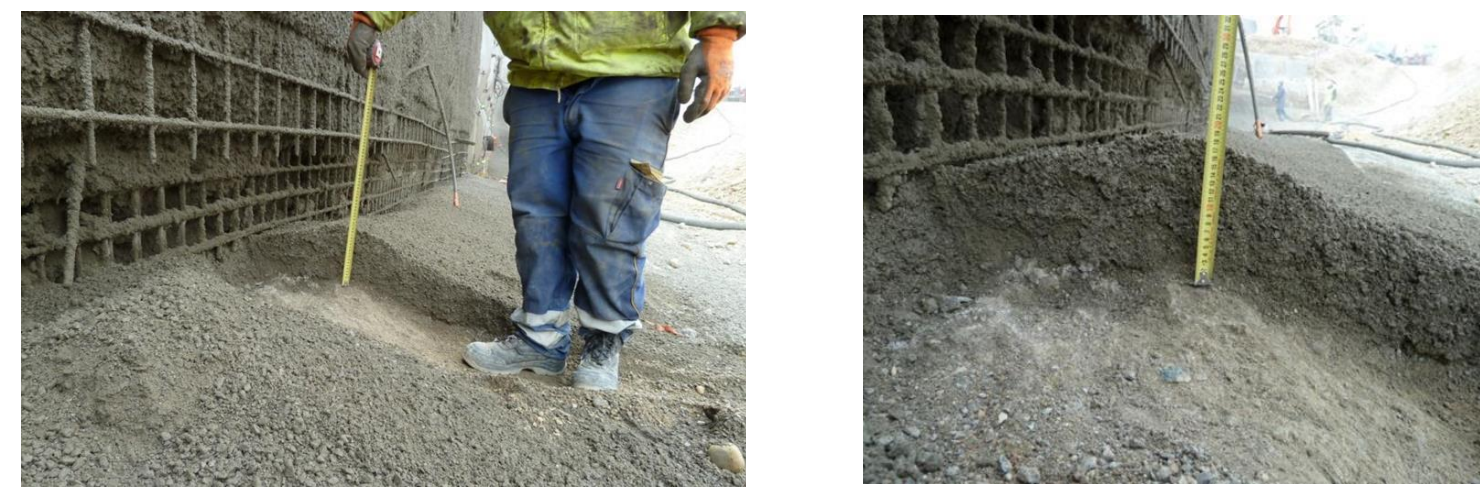

Figure 11. Wasted concrete due to rebound during shotcrete application

On the right side of the soil nailed experimental wall, the facing was constructed with the new technique based on prefabricated panels. A schematic soil nailed wall with the new precast panel facing is presented in Figure 12(a). For each excavation stage (corresponding to a row of soil reinforcements), a series of precast panels are progressively placed so that the central hole of the panels coincide with a reinforcement head. A mechanical device assembles adjacent corners of the panels (see connection device in Figure 2). Finally, a 4/6 mm crushed material is injected in-between the vertical cut in the ground and the back of the panels, precisely installed according to the project plans.

The most important aspect of the new technique is the injection of the $4 / 6 \mathrm{~mm}$ crushed material, through the weep holes managed along the four sides of the prefabricated panels, which applies an immediate confining pressure to the vertical cut in the ground and provides continuous high capacity drainage behind the facing. In the conventional shotcrete construction technique of soil nailed walls, installation of drainage complex and short term application of soil support are conflicting operations which results in possible poor drainage performance, leading to most observed failures of soil nailed walls. Injection of a tick draining layer behind the facing panels also prevents from frost heave pressures due to water transport caused by freezing water in silty soils.

A picture of this material is shown in Figure 12(b). To facilitate its placement behind the panels and to avoid runout of the material below the panel during the next excavation stage, it was found very convenient to prepare a slightly cemented wet mixture. In practice, the $4 / 6 \mathrm{~mm}$ crushed rock is first wetted and drained. Then, about $50 \mathrm{~kg}$ of cement per cubic meter of draining material is mixed to the wetted $4 / 6 \mathrm{~mm}$ crushed rock. This wet mixture behaves like a fluid, which can easily be pumped behind the facing panels through the weep holes. Finally, a 
slight tension may be applied at the anchor's head to ensure regular distributed pressure behind the facing panel and to apply a first confining pressure to the yet unsupported soil next to the facing. Within a few hours, the rock particles of the mixture are bonded to each other through cement menisci appearing along the particle's edges. Unconfined compressive strength after one day cure of this material was found larger than $1 \mathrm{MPa}$ and indirect unconfined tensile strength larger than $0.2 \mathrm{MPa}$ (Brazilian test). With a porosity close to $50 \%$, a permeability greater than $10^{-3} \mathrm{~m} / \mathrm{s}$ was observed in the laboratory.

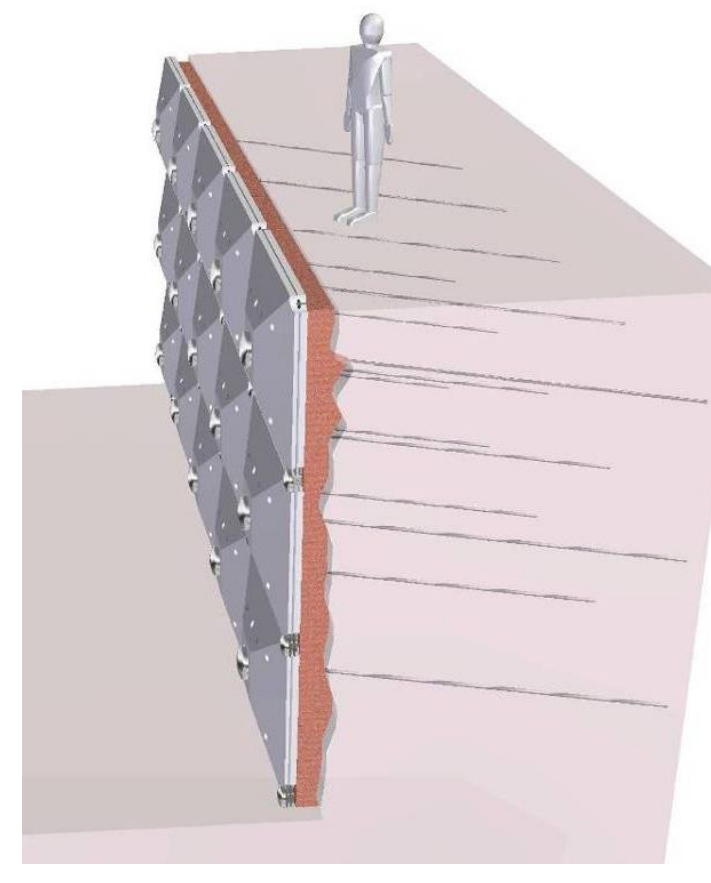

(a) Schematic view

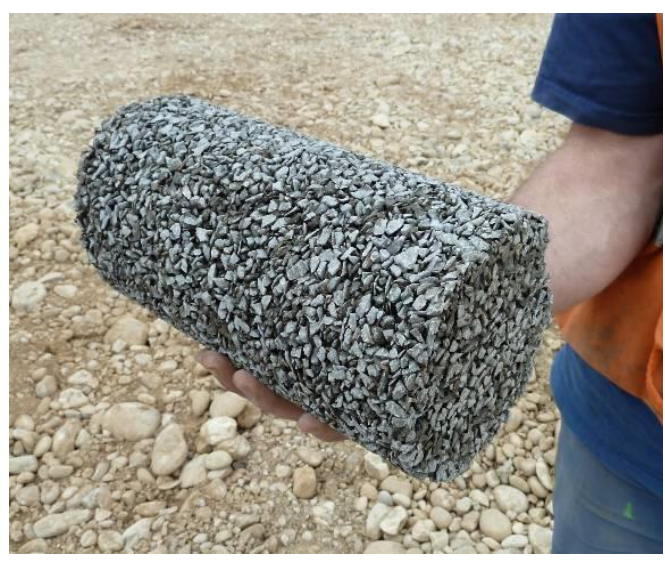

(b) Sample of the $4 / 6 \mathrm{~mm}$ crushed material injected for drainage of facing

Figure 12. (a) Detail of the new construction technique for soil nailed wall facing, (b) material injected for draining

Figure 13 shows the installation of the panels for the first row of soil reinforcements. A temporary suspension bracket was designed to hold the precast panels, to avoid any downwards sliding of the facing during the successive excavation stages. Sliding would have induced unexpected shear forces at the reinforcement heads. In fact, with the new technique, presented in detail in the preceding, it turned out that such suspension brackets are not required. Thanks to the cemented $4 / 6 \mathrm{~mm}$ crushed material injected behind the panels, vertical displacements of the facing during construction may be considered to be close to those of a conventional shotcrete facing, at a site favorable to this last technique. 


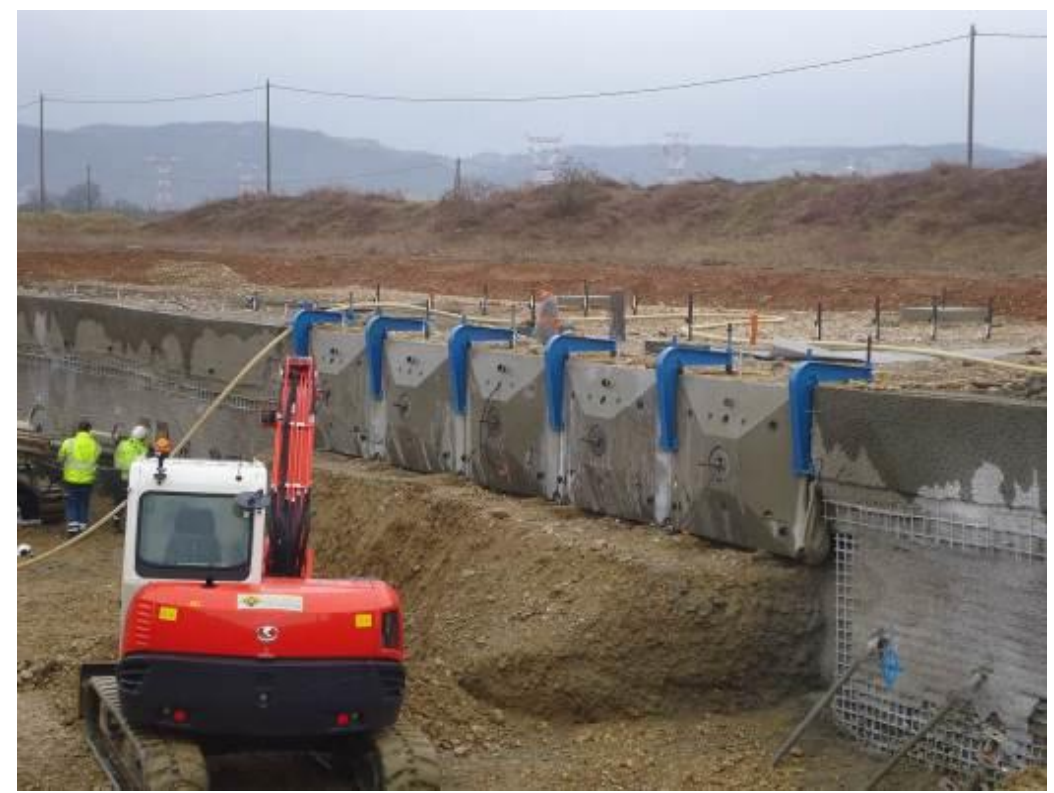

Figure 13. Temporary suspension brackets to avoid vertical sliding of the first panel row

During construction of the facing for the following rows of soil reinforcements, a mechanical device (see Figure 2) will connect the upper corners of each new panel to the lower corners of the above panel and its lower corner to the adjacent panel installed just before in the same row. As a consequence, in the new construction technique, the location of the borings for the soil reinforcements has to be precisely located with respect to the panels installed during the preceding stage. Using a drilling jig connected to the lower corners of the panel above, the $5 \mathrm{~cm}$ allowance thanks to a central hole in the panel larger than the bar diameter (Figure 2) turned out to be easily achieved during construction of the experimental wall.

\section{Performance of the new construction technique}

\subsection{Environmental and economic performance}

The construction of the experimental soil nailed wall was an opportunity for objective comparison, in terms of environmental and economic performance, of the two constructive techniques used for the facing. In such an analysis, the foremost aspect to be emphasized of course is the worker's safety, greatly improved with the new construction technique, which eliminates injuries related to shotcrete application.

The other aspects of environmental and economic performance considered were the amount of concrete and steel required for each technique, the overall duration for constructing each strip of facing (corresponding to one horizontal row of soil reinforcements) and the cost related to the use of equipments needed in the construction processes. 
In the project, the part of facing to be built using each technique was $10 \mathrm{~m}$ long by $7.5 \mathrm{~m}$ high $\left(75 \mathrm{~m}^{2}\right)$. During construction of the experimental soil nailed wall at the site, consumption of concrete and steel reinforcing rebars for in situ construction of the facing from several shotcrete layers was recorded. According to the design, the thickness of the facing was to be $25 \mathrm{~cm}$. As indicated in Table 3, to build $100 \mathrm{~m}^{2}$ of facing at the site with the shotcrete technique would require $52 \mathrm{~m}^{3}$ of concrete. About $32 \%$ of concrete was lost during shotcrete application. Due to out of profile resulting from soil excavation or from ground disturbance when drilling for installing the soil reinforcements, the actual average thickness of shotcrete at the facing turned out to be rather of the order of $35 \mathrm{~cm}$.

Table 3. Concrete and steel rebars quantities for construction of a $100 \mathrm{~m}^{2}$ soil nailed wall facing using either the conventional shotcrete technique or the precast panels.

\begin{tabular}{|c|c|c|c|c|}
\hline Supplies & \multicolumn{2}{|c|}{ Shotcrete } & \multicolumn{2}{c|}{ Precast panels } \\
\hline Concrete & $52 \mathrm{~m}^{3}$ & $17.9 \mathrm{t}_{\text {of } \mathrm{CO}_{2}}$ & $18.7 \mathrm{~m}^{3}$ & $6.4 \mathrm{t}$ of $\mathrm{CO}_{2}$ \\
\hline Steel Rebars & $1920 \mathrm{~kg}$ & $4.1 \mathrm{t}$ of $\mathrm{CO}_{2}$ & $1500 \mathrm{~kg}$ & $3.2 \mathrm{t}$ of $\mathrm{CO}_{2}$ \\
\hline Total & \multicolumn{2}{|c|}{$22 \mathrm{t} \mathrm{of} \mathrm{\textrm {CO } _ { 2 }}$} & \multicolumn{2}{c|}{$9.6 \mathrm{t} \mathrm{of} \mathrm{CO}_{2}$} \\
\hline
\end{tabular}

With the new technique, the quantity of concrete needed to build $100 \mathrm{~m}^{2}$ of facing is about $18.7 \mathrm{~m}^{3}$, corresponding to the volume of about 33 precast panels. Thus, compared to the shotcrete construction technique, the new technique reduces concrete consumption by $64 \%$. Part of this difference in concrete consumption corresponds to the cemented $4 / 6$ crushed stone injected through the weep holes to fill out the voids between the excavation surface and the back side of the panels. For a $100 \mathrm{~m}^{2}$ facing with the new technique, about $15 \mathrm{~m}^{3}$ of $4 / 6$ cemented crushed stone and about $0.75 \mathrm{t}$ of cement are also required.

As mentioned in Table 3, the quantity of steel rebars needed for constructing the facing is reduced by about $22 \%$ with the new technique. The significant reduction in construction materials (concrete and steel) leads to a substantial construction cost reduction. Manufacturing of concrete (mainly the cement) and steel generates large amounts of greenhouse gases (GHG). In Table 3, for the construction of a $100 \mathrm{~m}^{2}$ soil nailed wall facing, the emission of greenhouse gases corresponding to the supply of concrete and steel have been evaluated for each construction technique in terms of equivalent $\mathrm{CO}_{2}$ according to ADEME's Base Carbone ${ }^{\circledR}$ references [15]. The new technique cuts down the emission of GHG by at least $56 \%$.

In addition, the new construction technique for the facing of soil nailed walls based on precast panels eliminates the constraints on construction sequences related to the application of consecutive shotcrete layers. Usually, a delay of 24 hours is necessary for the first layer of 
shotcrete to set and to install the second welded mesh of the reinforced concrete wall. Then, the second shotcrete layer is applied and, again, a minimum delay of 24 hours is usually required for the facing to gain some strength before proceeding to the next excavation stage. With the new technique, construction time and constraints on work's schedule are thus significantly reduced, since installing one row of facing panels and injecting the cemented $4 / 6$ crushed stone is much faster than applying only the first shotcrete layer at the construction site.

\subsection{Mechanical performance}

The experimental full-scale soil nailed wall has been instrumented to compare the influence of the two construction techniques on the mechanical behaviour. Both parts of the wall, the first one with shotcrete facing and the second one with precast panels, were equipped with the same instrumentation plan. Ground settlements behind the wall, vertical and horizontal displacements of the facing and distribution of tensile forces along the soil reinforcements have been observed during and after construction for almost two years.

The results have been analysed in detail by Jean de Sauvage [16] in his study on the design of the facing of soil nailed walls. The main conclusions, presented here, only pertain to the influence of the new facing construction technique on the mechanical behaviour of the wall. Figure 14 shows an elevation view of the whole facing, symmetric with respect to the vertical profile at the centre of the wall, with shotcrete facing on the left and precast panels on the right. The lateral displacements of the facing in the vertical profiles at the centre of each construction technique were found to be close to each other, slightly lower in the precast panels section.

Several grouted steel bars of the soil reinforcements were equipped with strain gages. The three lowest horizontal lines of soil reinforcements were considered. Each instrumented reinforcement was equipped with strain gages at different distances from the facing to study the distribution of tensile force along the reinforcement. At each point along the reinforcement bars, two strain gages were installed, along the upper generatrix of the steel bar and along the lower, in order to distinguish flexure from tension. 


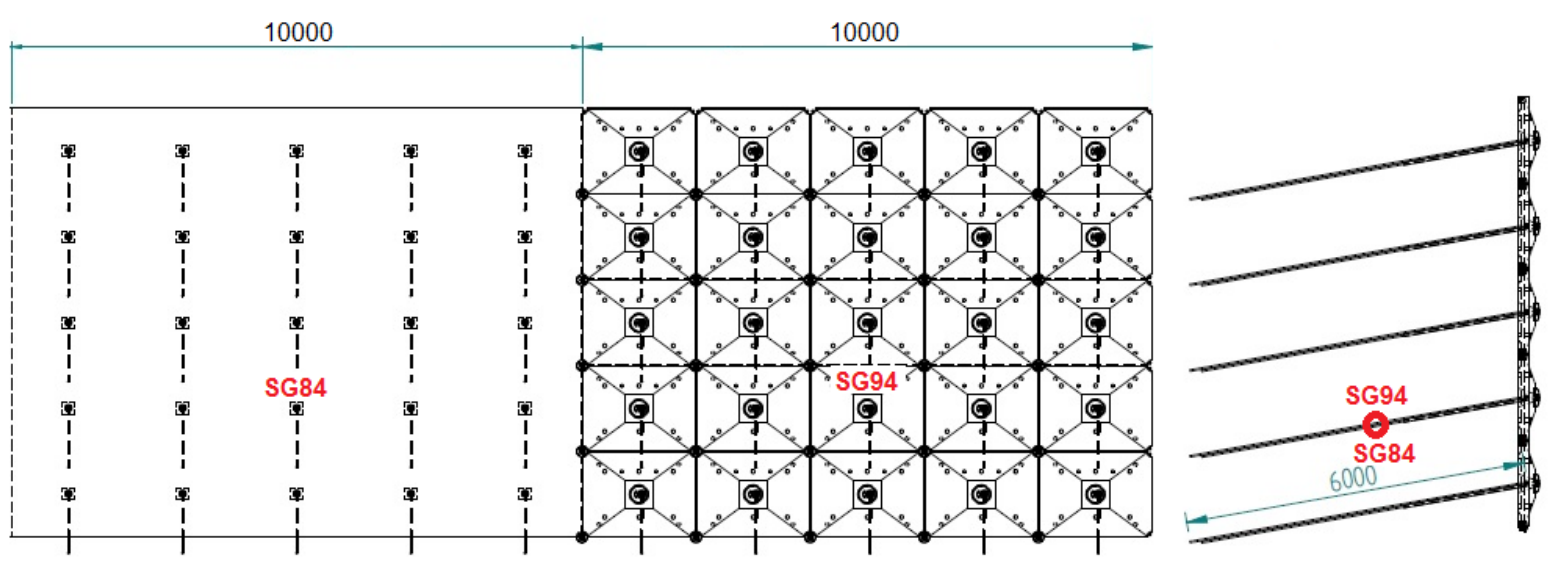

Figure 14. Location of strain gages SG84 and SG94 in the elevation view and cross section of the experimental wall

For both facing construction techniques, in all levels of soil reinforcements and at all distances from the facing, the tensile forces in the soil reinforcements were observed to be lower than expected according to the geotechnical design. The long term (observed 640 days after construction) maximum tensile force in the soil reinforcements, of the order of $60 \mathrm{kN}$, was observed in the second line of reinforcements from the base of the wall.

This low value of maximum tensile force compared to the design value is believed to be due to an underestimation of the soil shear strength and to the choice of the soil reinforcement's length larger than required by the design. This choice was made to definitely eliminate a possible failure related to pull out of the soil reinforcements, in order to focus the study on the facing. The conventional design method, based on limit equilibrium calculations, thus without considering the influence of construction stages, from top to bottom, on the loading of soil reinforcements, also leads to an overestimation of the maximum tensile forces, predicted to occur in the lowest line of reinforcements, which is never the case. A complete analysis of the influence of reinforcement's length on tensile force magnitude and distribution along the reinforcements may be found in Jean de Sauvage [16].

Nevertheless, tensile forces observed in the soil reinforcements were found to be lower in the precast panel facing part of the wall than in the shotcrete facing part. This indicates that the new facing construction technique, with faster application of a confining pressure to the soil during the construction process, leads to a lower soil disturbance within the volume of nailed soil and thus to lower efforts along the soil reinforcements.

For illustration, Figure 15 compares measurements in the strain gages installed on the grouted steel bars of the soil reinforcements at the same location in each part of the soil nailed wall, with shotcrete facing or with precast panels facing. The location of these strain gages was indicated in Figure 14. Both SG84 strain gages were installed in the central profile of the wall 
portion built with shotcrete facing, along the soil reinforcement in the next to last row, $3 \mathrm{~m}$ away from the facing. Extensions "- 01 " and "-02" refer to the upper and lower generatrix of the steel bar. Similarly, both SG94 strain gages were installed in the central profile of the wall portion built with precast panels facing, in the same row of soil reinforcements and at the same distance to the facing.

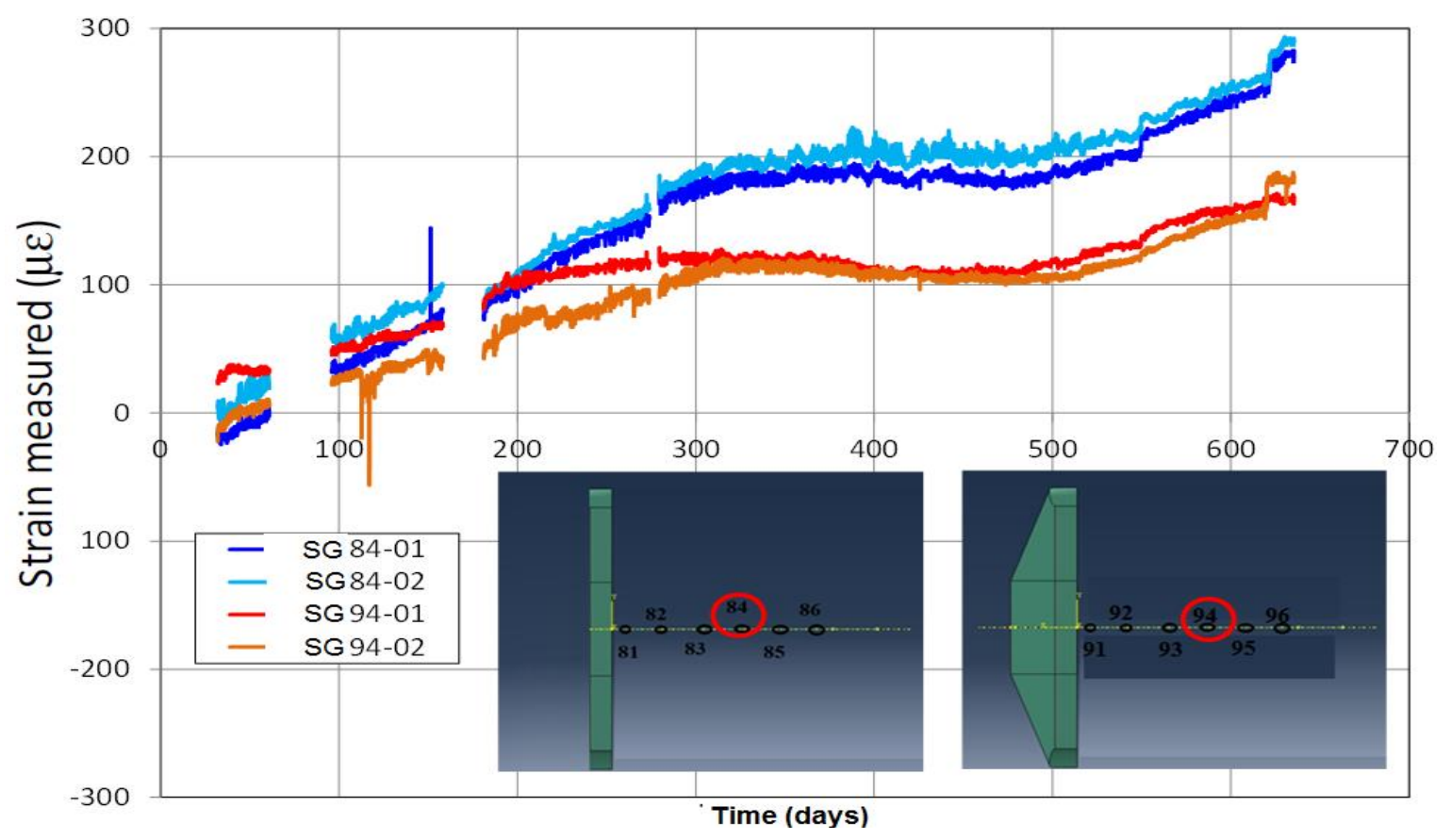

Figure 15. Strain in soil reinforcements at the same location in the shotcrete section of the soil nailed wall (SG84) and in the precast panel section (SG94)

Figure 15 shows that the measurements in SG84-01 and SG84-02 strain gages are close to each other, which indicate negligible flexure at that point. Similarly, flexure in the soil reinforcement is also low at point SG94. A $100 \mu$-strain deformation corresponds to a tensile force of about $10 \mathrm{kN}$ in the steel bar.

These graphs show that the tensile force in both reinforcements, at that distance from the facing, increased linearly with time for about 300 days and then reached a plateau. It is interesting to notice that apparent cohesion produced by soil expansion during excavation of unsaturated clean gravel needs about one year to dissipate, progressively reducing the soil shear strength and, as a consequence, loading the soil reinforcements for equilibrium. The tensile force corresponding to the plateau is significantly lower at point SG94, in the part of the wall with precast panels facing, than at point SG84, in the part of the wall with shotcrete facing.

Comparing tensile forces in the soil reinforcements at other similar locations, behind precast panel facing and behind the shotcrete facing, values were found systematically lower behind the precast panels facing than behind shotcrete facing, however with differences not so 
significant. This indicates that the new construction technique for the facing of soil nailed walls improves the performance of the soil nailing technique compared to the conventional construction technique of the facing based on shotcrete.

Finally, it may be noticed in Figure 15 that tensile forces in the reinforcements at points SG84 and SG94 began to increase again after about 520 days. This corresponds to the moment where a trench $1.5 \mathrm{~m}$ deep was excavated at the toe of the soil nailed wall, in an attempt to produce and observe the wall failure. In fact, wall failure could not be reached, even when applying an additional surcharge at the top. To restore the site after experiment, the soil nailed wall had to be dismantled by excavation of the whole soil nailed volume.

\section{Conclusion}

In this study, a new technique for constructing the facing of soil nailed walls has been presented. Instead of the conventional technique based on shotcrete application, reinforced concrete precast panels are used. In the construction process, a slightly cemented 4/6 crushed stone is injected through weep holes, to fill the void between the back face of the panels and the ground excavation vertical wall. This new technique to build the facing greatly improves worker's safety, since it eliminates frequent injuries related to shotcrete application.

The structural design of the precast reinforced concrete panels has been presented in detail. It was based on laboratory tests performed on a single facing panel subjected to unfavourable mechanical loading conditions compared to the field, where the reinforcement applies a load at the centre and the soil a distributed pressure on the opposite surface. A numerical model was also developed to simulate the laboratory tests. Predictions of crack initiation and failure modes were in good agreement with the behaviour observed in laboratory tests. The reinforced concrete panel geometry and steel reinforcement, designed to sustain the ultimate axial load of the soil reinforcements, have been presented in detail.

A full-scale experimental soil nailed wall $7.5 \mathrm{~m}$ high was built at a site where the soil profile consisted of a very thick layer of dense clean gravel. Half of the facing was constructed using the conventional shotcrete technique and the other half with the new technique based on precast concrete panels. The purpose was to evaluate the environmental, economic and technical performance of the new construction technique compared to the conventional shotcrete method.

It was found that the new technique reduces concrete consumption by about $64 \%$ compared to the shotcrete construction technique, in which a significant quantity of concrete is 
lost, due to rebound on steel meshes and to poor adhesion to the draining complex or to the ground, or wasted due to out of profile resulting from soil excavation and from ground disturbance when drilling for installation of the soil reinforcements. The new technique as well reduces by about $22 \%$ the quantity of steel rebars needed for the facing.

Manufacturing of concrete (mainly the cement) and steel generates large amounts of greenhouse gases (GHG). As a consequence, according to ADEME's Base Carbone ${ }^{\circledR}$ references [15], the new technique cuts down the emission of GHG for construction of the facing of soil nailed walls by more than $56 \%$.

From the economic point of view, the new construction technique significantly reduces the overall construction cost of soil nailed walls. The cost reduction is mainly due to the lower quantity of construction material needed and to the shorter construction duration, since the constraints on construction sequences implied by the application of consecutive shotcrete layers are eliminated. Simply, when switching from shotcrete to precast panels, the company's practice has to get adjusted to the new construction process. But the outcome is worth it.

Finally, the construction of the instrumented full-scale soil nailed wall demonstrated the mechanical performance of the new technique for facing installation compared to the conventional shotcrete technique. Horizontal displacements of the facing and surface settlement behind the wall facing were observed slightly lower in the precast panels section of the experimental wall. Tensile forces in the soil reinforcements were systematically observed lower in the precast panels facing section than in the shotcrete facing section.

This indicates that the new construction technique for the facing of soil nailed walls improves the overall mechanical performance of the soil nailing technique compared to the conventional shotcrete construction technique. This may be due to the shorter delay before applying back a confining pressure to the excavation face, thus reducing soil disturbance in the ground. Besides, the new construction technique includes a continuous and high capacity drainage behind the facing, while in practice poor drainage of the facing is the main cause of soil nailed walls failure.

\section{Acknowledgments}

This research project was funded by NGE FONDATION, saint-Priest, France.

\section{References}

[1] Chavan, D., Mondal, G., Prashant, A. (2017). Seismic analysis of nail soil slope considering interface effects. Soil Dyn Earthq Eng 2017;100:480-91. doi:10.1016/j.soildyn.2017.06.024. 
[2] Colin JG, Chouery-Curtis VE, Berg RR. Field observations of reinforced soil structures under seismic loading. Proceedings of the international symposium on earth reinforcement. Fukuoka, Japan; 1992. vol. 1. p. 223-8.

[3] Tatsuoka F, Tateyama M, Koseki J, Uchimura T. Geotextile-reinforced soil retaining wall and their seismic bahaviour. Proceedings of 10th Asian regional conference on soil mechanics and foundation engineering, vol. 2; 1995. p. 26-49.

[4] Juran I. Nailed-soil retaining structures: Design and practice. Transp Res Rec 1987:139-50.

[5] Bruce, D. A., \& Jewell, R. A. (1986). Soil nailing: application and practice-part 1. Ground Engineering, 19(8), 10-15.

[6] Schlosser F, Unterreiner P, Plumelle C. Validation of calculation methods of soil nailed walls based on the experimentations of the National Project CLOUTERRE. Rev Fr Geotech 1993:11-20. doi:10.1051/geotech/1993064011.

[7] Menkiti CO, Long M. Performance of soil nails in Dublin glacial till. Can Geotech J 2008;45:1685-98. doi:10.1139/T08-084.

[8] Bui T T, Limam A 2015 Paroi Clouée Préfabriquée: Evaluation de la capacité portante d'une écaille constitutive: approche expérimentale et numérique, Internal report, France.

[9] Menkiti CO, Long M, Milligan GWE, Higgins P. Soil Nailing in Dublin Boulder Clay. Geotech Geol Eng 2014;32:1427-38. doi:10.1007/s10706-013-9679-6.

[10] Bui T T, Limam A 2015 Parois Clouées : Suivi du comportement sur chantier Internal report, France.

[11] Lee J, Fenves G 1998 Plastic-damage model for cyclic loading of concrete structures Journal of Engineering Mechanics vol 124 pp 892-900.

[12] Lubliner J, Oliver J, Oller S, Oñate, E 1989. A plastic-damage model for concrete International Journal of Solids and Structures vol 25 pp 299-326.

[13] WSA Nana, T.T.Bui, Limam A, Abouri S 2017. Experimental and Numerical Modelling of Shear Behaviour of Full-scale RC Slabs Under Concentrated Loads. Structures, Elsevier, Volume 10, Pages 96-116. DOI:10.1016/j.istruc.2017.02.004.

[14] T.T.Bui, A.Limam, W.S.A.NaNa, T.Roure, B.Arrieta, 2018. Cast-in-place headed anchor groups under shear: Experimental and Numerical modelling. Structures, Elsevier, Volume 14, Pages 178-196.

[15] ADEME, Documentation des facteurs d'émissions de la Base Carbone ®, Version 11.0.0, novembre 2014, 280p.

[16] Jean de Sauvage, «Etude du comportement des murs de soutènement par clouage des sols en place : application au dimensionnement du parement », $\mathrm{PhD}$ doctoral dissertation », IFSTTAR, Bron, 30/11/2018. 